\title{
Wielomodalne monitorowanie postępu zmian zmęczeniowych w stalowych elementach konstrukcji
}

\author{
Multimodal monitoring of damage \\ in steel construction elements during fatigue life
}

\section{Streszczenie}

W artykule przedstawiono koncepcję wielomodalnego systemu monitorowania zmian stanu konstrukcji stalowych zachodzących w wyniku oddziaływania obciążenia zmieniającego się $\mathrm{w}$ czasie. $\mathrm{W}$ celu monitorowania różnych aspektów zmian zachodzących w strukturze materiału w procesie degradacji, zaproponowano dwa podsystemy umożliwiające przeprowadzenie zarówno globalnej, jak i lokalnej oceny stanu materiału. Do ogólnej obserwacji wielkości zmian zachodzących w wyniku zmiennych warunków obciążenia, stanu naprężeń i zakresu obszarów odkształceń plastycznych, zastosowano termografię podczerwoną (IRT) i metody elektromagnetyczne niskich częstotliwości związane z monitorowaniem procesu magnesowania polem AC (EM). Natomiast do badania obszarów krytycznych, zagrożonych powstawaniem odkształceń plastycznych w wyniku oddziaływania składowej siły obciążającej stałej w czasie użyto metodę IRT przy wsparciu metody mikrofalowej (MW). Połączenie tych trzech metod badań nieniszczących NDT daje możliwość uzyskania pełniejszej informacji o stanie badanej struktury.

Słowa kluczowe: monitorowanie degradacji stali; aktywna termografia podczerwona; czujniki mikropaskowe; pomiary mikrofalowe; metoda szumów Barkhausena; metoda magnetyzacji AC

\begin{abstract}
In this paper a new approach to state assessment of steel structures under a dynamic load conditions is presented. In order to monitor different aspects of material's structural changes during fatigue process, two sets of measuring methods allowing both global and local evaluation of the structure are utilized. In order to monitor general changes state under cyclic loading conditions, together with stress level and formation of plastic deformation areas, an infrared thermography (IRT) and low frequency range electromagnetic methods related with monitoring of AC magnetization process (EM) are used. Then for examination of critical plastic deformation area under static loading conditions a IRT method with support of microwave (MW) one are applied. The combination of the three methods of NDT (Non-Destructive Testing) techniques allows to obtain a more complete description of the tested structure.
\end{abstract}

Keywords: steel degradation monitoring; active infrared thermography; microstrip sensors; microwave measurements; Barkhausen noise method; AC magnetization method

\section{Wstęp}

Proces zniszczenia zmęczeniowego materiału jest obecnie jedną z głównych przyczyn uszkodzeń i awarii mechanicznych występujących w przemyśle [2]. Takie uszkodzenia mogą powodować duże straty finansowe, a nawet być przyczyną katastrof skutkujących poważnymi konsekwencjami. Dlatego właściwa ocena przebiegu procesu zmęczenia i przewidywanie przyszłego czasu pracy konstrukcji jest jednym z głównych problemów obszaru usług serwisowych i utrzymania ruchu. Aby zminimalizować ryzyko wystąpienia niespodziewanych awarii, coraz częściej stalowe elementy konstrukcyjne są poddawane ciągłemu monitorowaniu ich stanu - systemy SHM (ang. structural health monitoring), z wykorzystaniem różnych metod NDT.

W procesie postępującego zniszczenia materiału można wyróżnić trzy główne fazy [1]: etap zmiany mikrostruktury zakończonej fazą przełomu zmęczeniowego,

Dr inż. Grzegorz Psuj; dr Barbara Szymanik; dr inż. Przemysław Łopato; mgr inż. Michał Herbko; mgr inż. Michał Maciusowicz - Zachodniopomorski Uniwersytet Technologiczny w Szczecinie, Wydział Elektryczny, Katedra Elektrotechniki Teoretycznej i Informatyki.

Autor korespondencyjny/Corresponding author. gpsuj@zut.edu.pl 
następnie - faza wzrostu obszaru rozwoju pęknięć na powierzchni materiału i ostatecznie zniszczenie materiału. Dynamika postępu każdego etapu zależy od wielu czynników związanych ze strukturą materiału, gładkością powierzchni, stanem naprężeń pozostałościowych i poziomem sił obciążających [2]. W warunkach rzeczywistych elementy konstrukcyjne $\mathrm{w}$ trakcie eksploatacji są narażone na oddziaływanie zarówno stałych, jak i zmiennych w czasie obciążeń. Dlatego podczas oceny degradacji materiału obie te charakterystyki powinny być brane pod uwagę i takie podejście zostanie zastosowane w niniejszym artykule. Uwzględniając powyższe wymagania, przedstawiona zostanie koncepcja połączenia możliwości trzech różnych metod pomiarowych do globalnej i lokalnej oceny degradacji konstrukcji stalowych, w wyniku oddziaływań statycznych i cyklicznie zmiennych obciążeń. Niedawno uzyskane wyniki zastosowania termografii podczerwonej (IRT), a także technik elektromagnetycznych do ciągłej obserwacji zmian stanu zmęczenia [3,14], potwierdziły możliwość wykorzystania obu metod do ogólnej oceny postępów procesu deformacji i zniszczeń zmęczeniowych. Jednak ze względu na uwarunkowania praktyczne ich zastosowanie do stałej obserwacji (w przypadku IRT) lub monitorowania dużych powierzchni (w przypadku EM) jest znacznie ograniczone [3]. Dlatego w tym artykule, w celu oszacowania globalnego stanu konstrukcji, monitorowania koncentracji naprężeń i deformacji plastycznych prowadzących do selekcji obszarów krytycznych, zostanie użyta metoda IRT wsparta metodami EM (obserwacji przebiegu procesu magnesowania polem AC oraz metody szumów Barkhausena). Ponadto, w krytycznych obszarach, w których może dojść do rozrostu odkształceń, zastosowana zostanie technika mikrofalowa MW.

\section{Metodyka badań}

W celu oszacowania wpływu obu typów sił na przebieg procesu degradacji, eksperymenty przeprowadzono osobno w warunkach obciążenia statycznego i cyklicznie zmiennego. Podczas eksperymentów użyto dwóch typów stali konstrukcyjnej: St3s - oznaczenie zgodnie z PN-88 H-84020 (zamiennik S235JRG2 zgodnie z EN 10025) i S355J2G3 - oznaczenie zgodne z EN10025. Kształt zastosowanych próbek z naniesionymi wymiarami i zaznaczanym obszarem pomiarowym (oznaczenie ROI) przedstawiono na rysunku 1. W przypadku próbek statycznie obciążanych, do przeprowadzenia lokalnego monitorowania obszaru największych deformacji, materiał nacięto po obu bokach (rys. 1a.), zawężając obszar oddziaływania największych sił. Umożliwiło to precyzyjne prowadzenie bieżącej obserwacji wpływu zmian materiałowych na rejestrowane dane. Natomiast w przypadku monitorowania zmian zachodzących $w$ trakcie procesu cyklicznie zmiennego użyto próbek o kształcie umożliwiającym uzyskanie bardziej jednorodnego rozkładu przemian materiałowych na większej powierzchni. W ten sposób możliwe było uzyskanie mniejszej dynamiki zmian zmęczeniowych.

Pierwszą z proponowanych metod badań nieniszczących jest termografia aktywna z zewnętrznym źródłem energii do wymuszenia przepływu ciepła $[4,20]$. W eksperymencie ze statycznym obciążeniem, źródłem energii było samo obciążenie, któremu poddawana była badana próbka. W eksperymencie z obciążeniem cyklicznie zmiennym wykorzystano wzbudzenie lampami halogenowymi. W przypadku stali poddawanej obciążeniom mechanicznym przepływ ciepła jest generowany poprzez tarcia wewnętrzne, powodujące rozproszenie energii na skutek powstałych naprężeń i sił ściskających. Defekty w strukturze wewnętrznej badanego materiału wpływają na proces generowania ciepła. W zależności od rodzaju zachodzącej zmiany temperatura może się obniżać (w wyniku ściskania próbki), rosnąć (gdy próbka się rozciąga) lub pozostawać stała (w momencie pęknięcia). Próbkę poddawaną cyklicznie zmiennym obciążeniom mechanicznym analizowano przed i po procesie zmęczeniowym. Zadane obciążenie dynamiczne wywołało zmiany w strukturze mikrokrystalicznej stali, widoczne jako zimniejsze lub przegrzane miejsca w czasie obserwacji stali podczas ogrzewania lampami halogenowymi oraz w trakcie jej naturalnego ochładzania.

Podczas monitorowania procesu statycznego obciążania próbki, metoda termowizyjna wspierana była przez odczyty z mikrofalowych przetworników wykonanych w technice mikropaskowej. Antenowe czujniki mikropaskowe mogą służyć do monitorowania wzrostu naprężeń i pęknięć w materiale przewodzącym [8,9]. Czujnik stosowany jedynie do pomiaru naprężeń składa się z trzech warstw: promiennika (z materiału przewodzącego naniesionego na izolator), izolatora i masy (płaszczyzna masy wykonana z materiału przewodzącego naniesiona na drugą stronę izolatora). Natomiast w przypadku monitorowania stanu powierzchni i wzrostu pęknięć, płaszczyznę masy czujnika antenowego stanowi badany materiał przewodzący. W niniejszej pracy zaproponowana została struktura mikropaskowa mająca zastosowanie w obu przypadkach. Powinna ona być umieszczona w miejscach, gdzie prawdopodobieństwo pęknięcia jest wysokie, np. w sąsiedztwie otworów i szczelin. Obecność i wzrost obszaru pęknięć w badanym materiale, jak również wydłużenie promiennika wynikające z odkształcenia materiału, wpływa na długość elektryczną struktury mikropaskowej. W następstwie zmianie ulega częstotliwości rezonansowa $\mathrm{f}_{\mathrm{r}}$ przetwornika, co może być monitorowane za pomocą wektorowego analizatora mi-

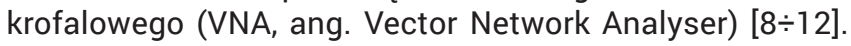
Przesunięcie częstotliwości jest liniowo związane z przyłożonym naprężeniem i długością pęknięcia $[9,10]$.

Do obserwacji wpływu obciążeń cyklicznych zastosowano aktywną termografię podczerwoną i techniki elektromagnetycznego testowania. Zmiany zachodzące w mikrostrukturze materiału w wyniku obciążania statycznymi i zmiennymi siłami wywołują zmiany właściwości magnetycznych i elektrycznych $[1,21,22]$. Dlatego poprzez śledzenie zmian właściwości magnetycznych możliwe jest przeprowadzenie oceny stopnia zniszczenia materiału. Charakterystyka zmian parametrów pętli histerezy magnetycznej takich, jak remanencja czy koercja oraz wartości charakterystyczne szumu Barkhausena takie, jak jego aktywność (liczba impulsów) czy energia wykazują silną zależność od liczby cykli zmęczeniowych i stanu niszczonego materiału. Magnetyczne metody badań nieniszczących umożliwiają określenie stanu zniszczenia materiału w sposób pośredni. Jednak wymagają one przeprowadzenia procesu kalibracji, co wynika z wpływu dużej liczby czynników oddziałujących na zmiany parametrów magnetycznych w trakcie cyklu życia materiału [1]. Dlatego też, zasadnym jest tworzenie wieloczynnikowych reguł i zależności w oparciu o liczne parametry sygnałów pomiarowych $[14,17,18]$.

\section{Badanie wpływu statycznej siły obciążającej}

Eksperyment przeprowadzono z wykorzystaniem próbek wykonanych ze stali St3s (rys. 1). Próbkę umieszczoną w maszynie hydraulicznej poddano procesowi rozciągania 
wzdłużnego, w trakcie którego obserwowano zachodzące zmiany przy użyciu zaproponowanych metod. Minimalna granica plastyczności dla badanej stali wynosi $235 \mathrm{MPa}$, a granica wytrzymałości mechanicznej $350 \mathrm{MPa}$. Krzywą odkształcenia otrzymaną w wyniku przeprowadzonego eksperymentu przedstawia rysunek 2a. Podczas badań laboratoryjnych wykorzystano aktywną termografię i metodę mikrofalową. Zdjęcie układu eksperymentalnego przedstawia rysunek 3. Kamera termowizyjna FLIR A325 rejestrowała obraz po jednej stronie próbki, a do drugiej przytwierdzono czujnik mikropaskowy. Pomiary wykonywano sukcesywnie po zmianie wartości zadawanego naprężenia w stałych odstępach ograniczonych czasem akwizycji danych. Procesy cieplne związane z powstającymi deformacjami rejestrowano w postaci sekwencji termogramów, a do pomiaru charakterystyki czujnika mikropaskowego (współczynnika odbicia S11) użyto sieciowego analizatora wektorowego. Strukturę i wymiary projektowanego czujnika przedstawia rysunek 3 . Bazuje on na standardowej antenie mikropaskowej o prostokątnym promienniku powszechnie wykorzystywanej w komunikacji bezprzewodowej [13]. Strukturę zmodyfikowano poprzez wycięcie w płaszczyźnie masy prostokątnego obszaru tożsamego z obszarem promiennika, co pozwoliło na obserwację zarówno naprężeń/odkształceń, jak i zmian powierzchni materiału wywołanych zewnętrznymi wymuszeniami mechanicznymi (np. wzrost porowatości lub pęknięć). a)

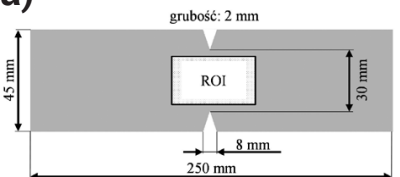

b)

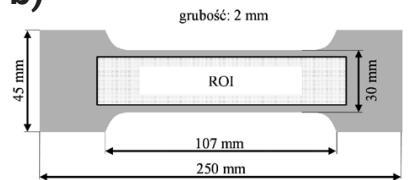

Rys. 1. Widok kształtu próbek z zaznaczonymi wymiarami i obszarem pomiarowym ROI wykonanych ze stali: a) St3s, b) S355J2G3

Fig. 1. View of the samples with depicted dimensions utilized in the experiments made of: a) St3s steel, b) S355J2G3 a)

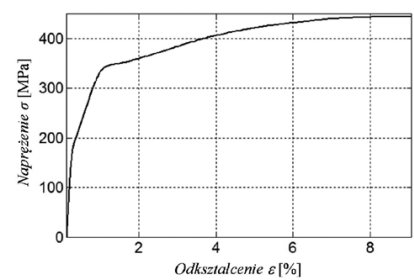

b)

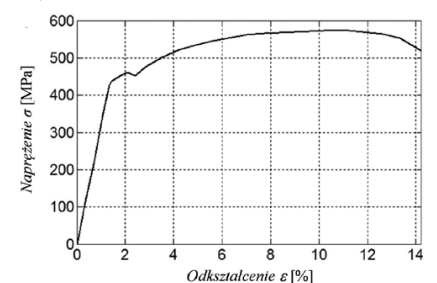

Rys. 2. Wykres zależności odkształcenia $w$ funkcji naprężenia uzyskanych dla próbek podczas eksperymentów dla stali: a) St3s, b) S355J2G3

Fig. 2. Stress-strain curve obtained during material examination for. a) St3s steel and b) S355J2G3 steel

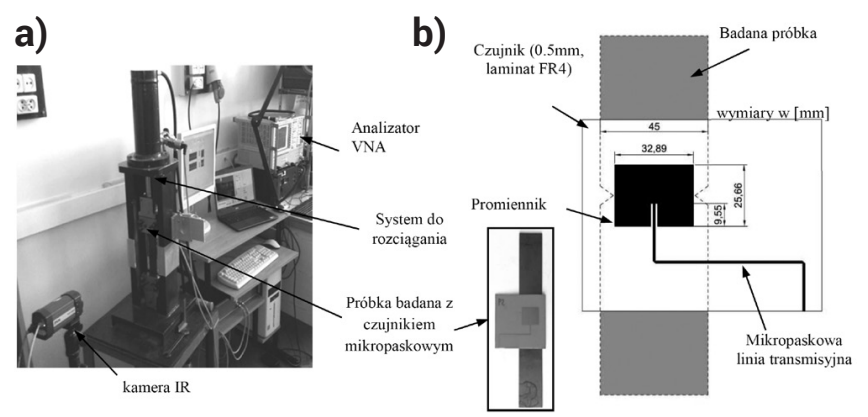

Rys. 3. System pomiarowy do badań materiałów poddawanych wymuszeniom statycznym: a) zdjęcie, b) widok czujnika mikropaskowego

Fig. 3. Measuring system for evaluation of the damage produced under static loading conditions: a) photo, b) view of microstrip sensor

\section{Badanie wpływu cyklicznie zmiennej siły obciążającej}

Eksperyment przeprowadzono dla próbek wykonanych ze stali konstrukcyjnej S355J2G3 (rys. 1b i 2b) [7]. Pomiary wykonano w dwóch seriach: przed i po zadaniu określonej liczby cykli zmęczeniowych. Minimalna wartość granicy plastyczności dla tego materiału wynosiła $355 \mathrm{MPa}$. Próbki obciążano wzdłużnie, cyklicznie zmienną siła o wartości maksymalnej nieprzekraczającej $300 \mathrm{MPa}$ używając maszyny hydraulicznej. Przed wykonaniem prób zmęczeniowych próbki wyżarzono przez godzinę $\mathrm{w}$ temperaturze $300^{\circ} \mathrm{C}$, a następnie pozostawiono do ostudzenia. Maksymalna liczba cykli poprzedzająca końcową serię pomiarową wynosiła $5,4 \cdot 10^{5}$. W celu oszacowania zakresu zmian zmęczeniowych w próbkach użyto metodę IRT wraz z metodą szumów Barkhausena i obserwacji parametrów procesu magnetyzacji polem AC (metody EM).

Pomiary metodą IRT przeprowadzono przy użyciu układu przedstawionego na rysunku 4a. Źródło ciepła (lampę halogenową) umieszczono po przeciwnej stronie próbki w stosunku do kamery monitorującej (tryb przejściowy). Próbkę pokrytą czarną matową farbą o emisyjności bliskiej jedności zamocowano w ramie chroniącej kamerę przed bezpośrednim promieniowaniem lampy halogenowej. Rejestrację obrazów termowizyjnych prowadzono w dwóch fazach, grzania (15 sekund) i chłodzenia (60 sekund), stosując częstotliwość akwizycji równą $60 \mathrm{~Hz}$.

System do pomiaru EM przedstawiono na rysunku 4b. Materiał $\mathrm{w}$ trakcie pomiarów magnesowano polem zmiennym o częstotliwości $30 \mathrm{~Hz}$ wytworzonym za pomocą cewki wzbudzającej nawiniętej na rdzeń typu C. Sekcje pomiarowe umożliwiają obserwację sygnałów napięciowych szumu Barkhausena $U_{\mathrm{BN}}$ i pętli magnesowania $\left(U_{B}, U_{H}\right)$. W trakcie badań mierzono sygnały proporcjonalne do natężenia pola magnetycznego i indukcji magnetycznej. Do obserwacji sygnału $\bigcup_{B N}$ użyto układu dwóch cewek $\mathrm{BN}_{1}$ i BN $\mathrm{BN}_{2}$ połączonych różnicowo. Pierwsza cewka, znajdująca się w bezpośrednim sąsiedztwie próbki pomiarowej, mierzyła sygnał użyteczny. Drugą umieszczono w pewnej odległości od materiału. Taka konfiguracja pozwoliła na zminimalizowanie wpływu niepożądanych zakłóceń zewnętrznych mierzonych sygnałów [7]. Stochastyczny charakter sygnału szumu Barkhausena wymaga zastosowania złożonych algorytmów analizy danych do określenia jego liczbowej reprezentacji. W tym celu przeprowadzono procedury ekstrakcji cech $[14,17]$ i dla każdego skupiska sygnału szumu Barkahsuena uzyskano zestaw parametrów. W pierwszej kolejności wykonano analizę statystyczną i wartości charakterystycznych bezpośrednio na podstawie uzyskanego sygnału napięciowego szumu Barkhausena. W konsekwencji uzyskano parametry takie, jak standardowe odchylenia lub energia skupiska. Następnie obliczono obwiednię sygnału skupiska szumu BN, dla której obliczono zestaw parametrów takich, jak wartość szczytowa, jej położenie i szerokość, mediana, odstęp międzykwadrylowy, skośność czy wartość połówkowa. Ze względu na wpływ naprężeń na kształt i dynamikę skupiska oraz aktywność szumu Barkhausena zastosowano również procedury analizy częstotliwościowej i czasowo-częstotliwościowej $[15,17,19]$. W ten sposób możliwe jest uzyskanie informacji na temat dynamiki procesu przemagnesowywania, a pośrednio na temat struktury badanego materiału. Zastosowanie metody magnesowania polem AC związane jest $\mathrm{z}$ monitorowaniem zmian parametrów mniejszościowych pętli histerezy $B(H)[7,15]$. Określenie 
parametrów pętli takich, jak koercja, remanencja czy przenikalność magnetyczna maksymalna i w punkcie nasycenia stwarza możliwość wykrycia zmian materiału $[7,14,16]$. Reprezentacja częstotliwościowa (widmo sygnałów) i harmoniczne mierzonych sygnałów $[7,17]$ dostarczają również użytecznych informacji. Obserwowane zmiany pętli zależą od stanu uszkodzenia materiału w badanym obszarze. a)

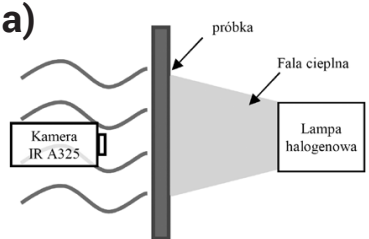

b)

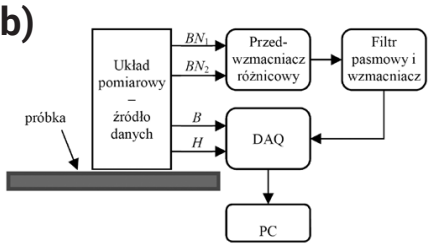

Rys. 4. Schemat konfiguracji systemów pomiarowych

Fig. 4. Diagram of the measuring systems' configurations

\section{Wyniki eksperymentów}

Określanie deformacji materiału wywołanych siłą statyczną

Podczas badań otrzymano zbiór sekwencji termogramów dla każdego poziomu naprężenia. Dla każdego obrazu wybrano i wycięto do dalszej analizy ten sam obszar zainteresowania ROI (rys. 1a). Wybrano kilka parametrów, które zostały obliczone dla obszaru wyciętego z każdego termogramu. Rysunek 5 przedstawia wykres zależności znormalizowanego odchylenia standardowego $S_{T} D_{n} z$ sekwencji obrazów rozkładów temperatury w obszarze ROI od poziomu zadanego naprężenia. Na otrzymanym wykresie rozróżnić można zakresy zachodzących zmian materiałowych. Po przejściu granicy $235 \mathrm{MPa}$, zauważalny jest niewielki wzrost odchylenia standardowego, którego dynamika zaczyna narastać po przekroczeniu $300 \mathrm{MPa}$. Największe zmiany widoczne są po przekroczeniu granicy wytrzymałości mechanicznej (zakres powyżej $350 \mathrm{MPa}$ ). a)

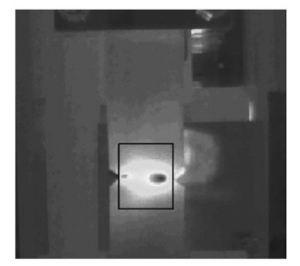

b)

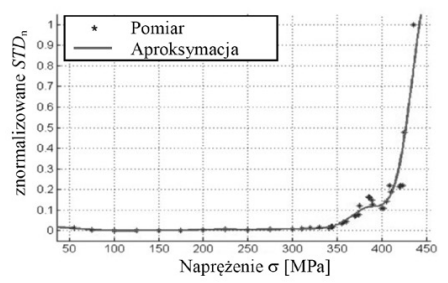

Rys. 5. Wyniki obserwacji metodą IRT w obszarze ROI: a) przykładowy obraz rozkładu promieniowania termicznego, b) wykres zależności wartości $\mathrm{STD}_{\mathrm{n}} \mathrm{w}$ funkcji $\sigma$

Fig. 5. Results of IRT inspection in ROI area: a) examplary IR image, b) normalized standard deviation $\mathrm{STD}_{n}$ versus stress $\sigma$

Równocześnie przeprowadzano pomiary przy użyciu przetwornika mikrofalowego, którego działanie oceniano w dwóch konfiguracjach:

- czujnik przymocowany do badanego materiału za pomo-

cą kleju (sztywne połączenie), po obu krańcach, poza obszarem promiennika,

- czujnik zamocowany tylko z jednej strony promiennika.

W przypadku pierwszej konfiguracji sztywne połączenie klejone umożliwia przenoszenie odkształceń próbki na przetwornik mikropaskowy. Deformacja materiału powoduje również wydłużenie promiennika, a zatem częstotliwość rezonansowa $f_{r}$ przetwornika zmniejsza się. Odchylenie $f_{r}$ określono jako:

$$
\Delta f=f_{r, x M P a}-f_{r, 0 M P a}
$$

gdzie: $f_{r, x M P a}$ - częstotliwość rezonansowa przy określonej wartości naprężenia x MPa, $\mathrm{f}_{\mathrm{r}, 0 \mathrm{MPa}}$ - częstotliwość rezonansowa dla próbki bez zewnętrznego naprężenia.

Wyniki doświadczenia przedstawia rysunek $6 a$. Zaobserwować można liniowe zmiany $\Delta \mathrm{f} z$ naprężeniem w elastycznym zakresie krzywej naprężenie-odkształcenie.

a)

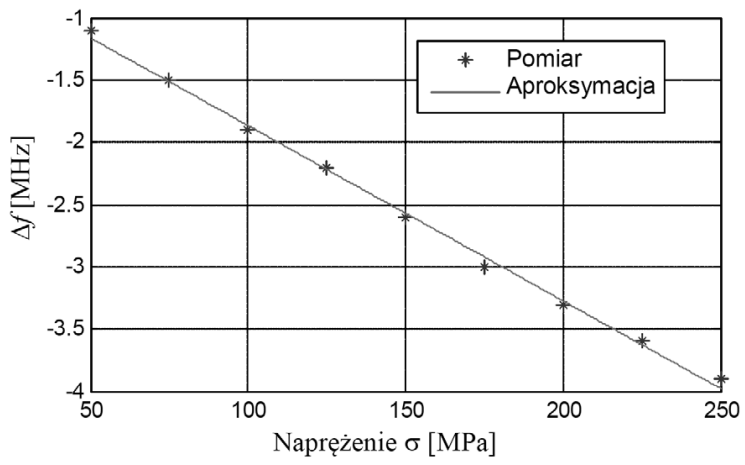

b)

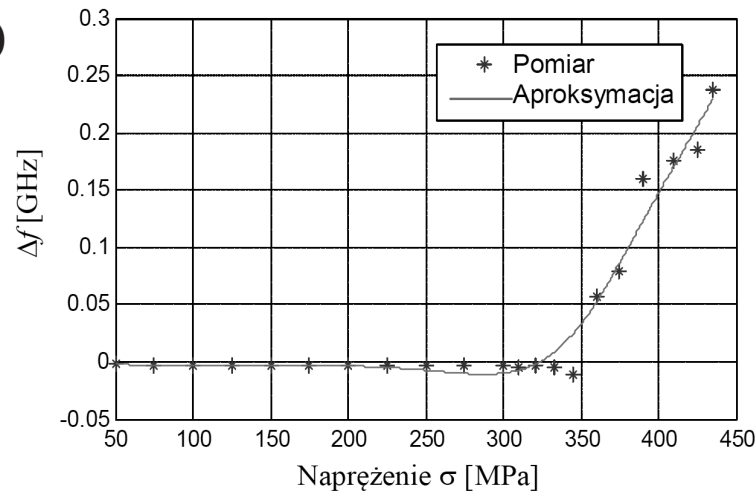

Rys. 6. Wyniki pomiarów metodą mikrofalową: a) określanie naprężeń w zakresie odkształceń sprężystych (czujnik przyklejony z obu stron promiennika), b) określanie naprężeń w zakresie odkształceń plastycznych (czujnik przyklejony tylko z jednej strony)

Fig. 6. Results of measurements: a) stress evaluation in elastic region of stress-strain curve (sensor fixed from both sides of patch), b) plastic deformation evaluation (sensor fixed only from one side of patch)

W przypadku drugiej konfiguracji czujnik nie jest deformowany przez odkształcenie próbki. Klej mocujący utrzymuje jedynie czujnik w sąsiedztwie materiału. Umożliwia to monitorowanie stanu powierzchni materiałów (z powodu bardzo małej głębokości penetracji prądów wysokich częstotliwości) i co za tym idzie wykrywania:

- wzrostu porowatości powierzchni (powodując zmianę powierzchniowej przewodności elektrycznej),

- lokalnego zwężenia materiału tuż przed powstawaniem pęknięć,

- powstawania i wzrostu pęknięć,

- całkowitego zniszczenia próbki.

Wyniki dla drugiej konfiguracji przedstawia rysunek 6b. Do punktu plastyczności odchylenie częstotliwości $\Delta f$ jest stałe. Po osiągnięciu $\sigma=350 \mathrm{MPa}, \Delta \mathrm{f}$ gwałtownie wzrasta. Odchylenie częstotliwości zmienia się od 0 do $250 \mathrm{MHz}$ w przypadku całkowicie uszkodzonej próbki. Średnia zmiana częstotliwości rezonansowej jest na poziomie $25 \mathrm{MHz} / \mathrm{MPa}$.

\section{Ocena zniszczenia materiału \\ wywołanego siłą cyklicznie zmienną}

Celem eksperymentu było sprawdzenie możliwości wykrycia zmian materiałowych po zadanej liczbie cykli zmęczeniowych. Dlatego badania przeprowadzono przed i po wykonaniu próby zmęczeniowej. Proces grzania lampami 
halogenowymi jest bardzo szybki, natomiast ochładzania (związany tylko z naturalną konwekcją) - dużo wolniejszy. Z uwagi na zmienną dynamikę obserwacja tych dwóch procesów może dać uzupełniające się rezultaty. Otrzymane wyniki poddano wstępnej obróbce (normalizacja obrazów): usunięto niejednorodności grzania, poprzez odjęcie od obrazu bazowego jego reprezentacji (dolnoprzepustowej) poddanej filtracji medianowej o dużej masce.

Technika aktywnej termografii posłużyła do wstępnej, globalnej oceny próbek, czyli do określenia, czy próbka została poddana obciążeniu cyklicznemu i wskazania prawdopodobnego umiejscowienia uszkodzeń jej mikrostruktury. Na podstawie sekwencji termogramów, zarejestrowanych podczas procesu nagrzewania próbki, obliczono średnią wartość AV sygnału otrzymanego w wyniku normalizacji obrazów (rys. 7a). W przypadku sekwencji z procesu ochładzania, obliczono odchylenie standardowe STD tego sygnału (rys. 7b). Największe zmiany wartości obserwowane na samych brzegach próbki powinny być pominięte, jako że są związane $z$ naturalną zmianą temperatury na krawędziach (w tym przypadku wzrostem - krawędź próbki stanowi barierę osłaniająca kamerę przed źródłem ciepła). W obu przypadkach dla próbki poddawanej obciążeniu cyklicznemu, wartości parametrów są wyższe od tych otrzymanych sprzed obciążenia. Rozkłady obu parametrów uzyskane dla pomiarów wykonanych przed procesem zmęczeniowym są praktycznie jednorodne. Natomiast po wykonaniu próby zmęczeniowej zauważalne są lokalne niejednorodności, które mogą świadczyć o zmianach zmęczeniowych. Do zweryfikowania wyników uzyskanych termografią użyto metod elektromagnetycznych EM. Znajdują one zastosowanie do dokładnej inspekcji obszarów krytycznych, które mogą być wytypowane na podstawie wyników uzyskanych metodą termograficzną. W [3] obserwowano zmiany parametrów magnetycznych w wybranym punkcie w sposób ciągły w trakcie trwania procesu zmęczeniowego. Obecnie w celu porównania wyników obu metod, pomiary wykonano w dwóch osiach dla całego obszaru ROI (rys. 1b) na dwóch etapach procesu zmęczeniowego, uzyskując informacje o zmianach na całej powierzchni próbki. Stosując procedury analizy opisane we wcześniejszym rozdziale dla każdego punktu pomiarowego otrzymano zestaw pięćdziesięciu dwóch parametrów. Rysunek 8 przedstawia wybrane znormalizowane (do wartości maksymalnej otrzymanej podczas badań) wyniki monitorowania postępu zniszczenia próbki przed (rys. 8a) i po (rys. 8b) przeprowadzeniu próby zmęczeniowej. Każda metoda umożliwia monitorowanie innego aspektu zmian struktury próbki. Rozkład $B N_{E N}$ pozwala obserwować zmiany koncentracji naprężeń w obszarze zainteresowania. W obszarze, gdzie pojawiły się pasma największych zniszczeń zobrazowanych przez lokalnie gwałtownie zmieniającą się wartość 1-szej harmonicznej sygnału $U_{H}$, zaobserwować można niski poziom $B N_{\mathrm{EN}}$. $Z$ drugiej strony, tworzenie się obszarów dużej koncentracji naprężeń na powierzchni poprzedza powstanie pasm deformacji, co można zaobserwować na podstawie wysokiej wartości $B N_{\mathrm{EN}}$ w tym obszarze.
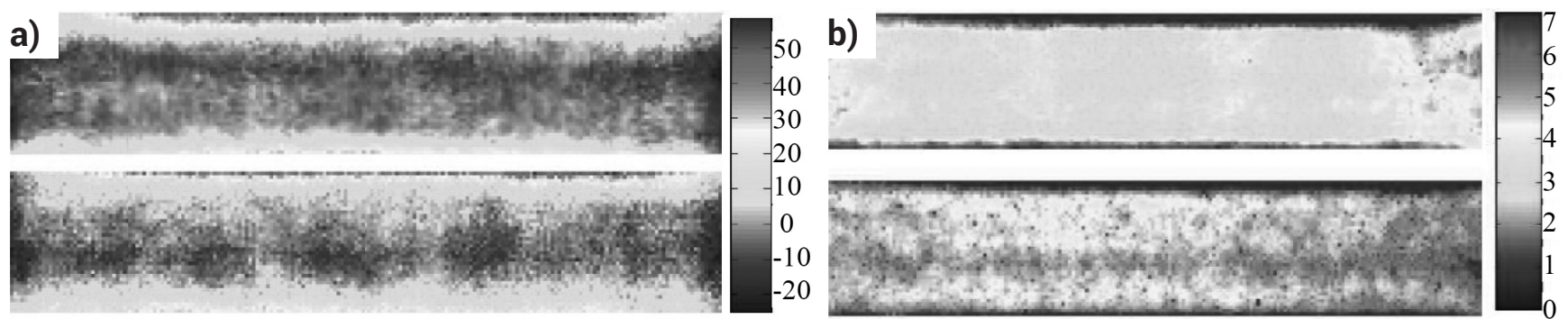

Rys. 7. Wyniki badania próbki metodą IRT: a) rozkład wartości AV na powierzchni próbki uzyskany dla fazy grzania: b) rozkład wartości STD na powierzchni próbki uzyskany dla fazy chłodzenia; górne obrazy - wyniki dla próbki przed wykonaniem próby zmęczeniowej; dolne obrazy - wyniki dla próbki po $5,4 \cdot 10^{5}$ cyklach zmęczeniowych

Fig. 7. The results of IRT inspection of the sample: a) mean value AV obtained for the heating phase, b) standard deviation value STD obtained for the cooling phase; upper images - sample before fatigue process, bottom images- sample after $5,4 \cdot 10^{5}$ fatigue cycles

a)

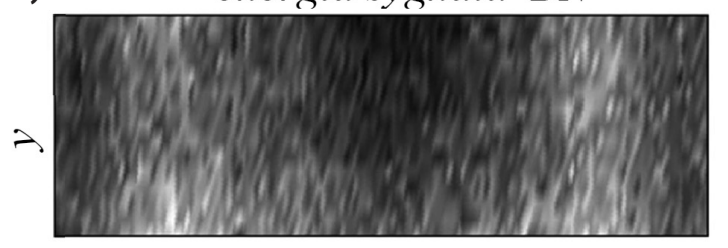

$x$

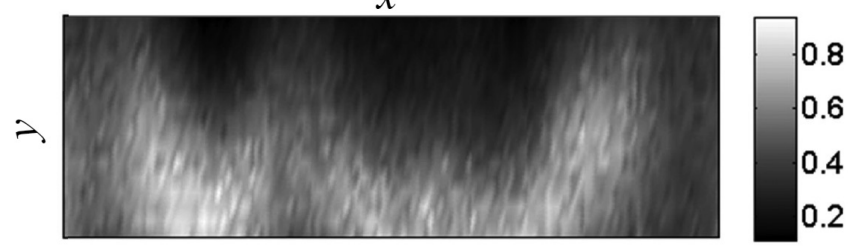

$x$

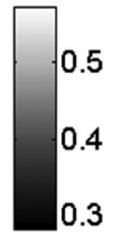

0.3 b)

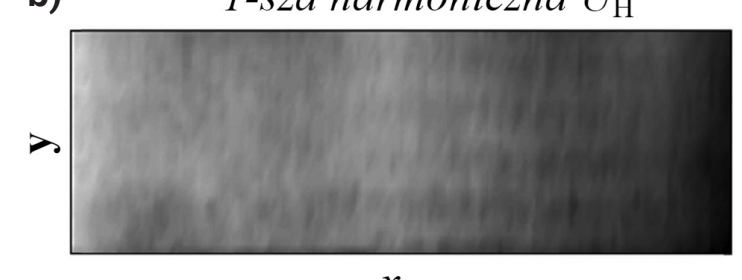

$x$
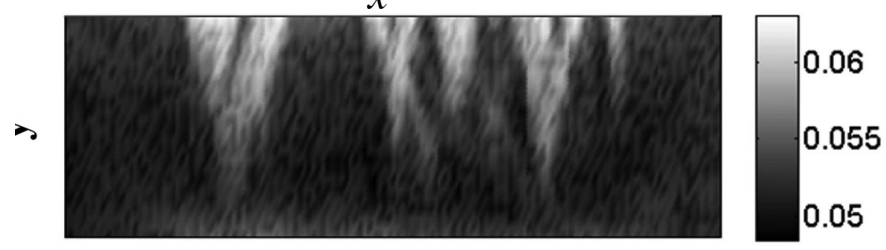

$x$

Rys. 8. Znormalizowane wyniki inspekcji przy użyciu metod EM: a) wyniki dla próbki przed wykonaniem próby zmęczeniowej, b) wyniki dla próbki po $5,4 \cdot 10^{5}$ cyklach zmęczeniowych; lewa kolumna - energia skupiska szumu Barkhausena, prawa kolumna - wartość pierwszej harmonicznej $U_{H}$

Fig. 8. Normalized results of EM inspection carried out for sample before fatigue process (a) and after $5,4 \cdot 10^{5}$ fatigue cycles (b); left column

- the energy of Barkhausen noise signal, right column - the 1 rst harmonic of $U_{H}$ 


\section{Wnioski}

W artykule podjęto próbę oszacowania stanu stalowych elementów konstrukcji bazując na połączeniu informacji uzyskanych z trzech uzupełniających się metod nieniszczących. Jest oczywiste, że wieloźródłowe podejście z użyciem metod pomiarowych polegających na monitorowaniu zmian różnych właściwości fizycznych lub w różnych warunkach stwarza możliwość uzyskania bardziej komplementarnych i w konsekwencji wyczerpujących informacji na temat stanu ocenianego materiału. Celem tych badań jest wypracowanie metodologii wielomodalnej inspekcji, która umożliwi oszacowanie postępu procesu deformacji i okresową ocenę zniszczeń stalowych elementów w praktyce. W rzeczywistych warunkach eksploatacji konstrukcje są narażone na oddziaływanie sił będących wypadkowymi statycznych i zmieniających się sił, co zostało uwzględnione w zrealizowanych badaniach. W celu oceny wpływu poszczególnych warunków obciążenia eksperymenty zostały przeprowadzone oddzielnie. Wyniki otrzymane w trakcie badania wpływu obciążeń statycznych pozwoliły na zaobserwowanie zależności pomiędzy wybranymi parametrami obu metod (tj. odchylenie standardowe temperatury i częstotliwości rezonansowej anteny), a wartością naprężenia. Istotną częścią przeprowadzonych eksperymentów było badanie relacji pomiędzy zmianami zachodzącymi w próbkach poddanych cyklicznie zmiennym siłom a parametrami metod pomiarowych. Uzyskane wyniki potwierdziły możliwość zastosowania metody aktywnej termografii do ogólnej oceny stanu badanego materiału w celu określenia czy uległ on zmianom zmęczeniowym i wytypowania potencjalnych obszarów największych zniszczeń. Zastosowanie metod elektromagnetycznych nisko- i wysokoczęstotliwościowych umożliwiło uzyskanie zależności ilościowych pomiędzy parametrami mierzonych sygnałów a stanem materiału. Celem dalszych prac będzie określenie optymalnych parametrów zastosowania przedstawionych metod pomiarowych oraz opracowanie systemu zarządzającego pracą i realizującego fuzję danych uzyskiwanych informacji za pomocą wszystkich metod.

\section{Autorzy pragną podziękować prof. Ryszardowi Sikorze i prof. Tomaszowi Chademu z Katedry Elektrotechniki Teoretycznej i Informatyki ZUT w Szczecinie za wsparcie, owocne dyskusje naukowe i uwagi dotyczące tematyki pracy.}

\section{Literatura}

[1] Palit Sagar S., et al.: Magnetic Barkhausen emission to evaluate fatigue damage in low carbon structural steel, International Journal of Fatigue, vol. 27, 2005, pp. 317-322.

[2] Dobmann G., Ciclov D. C., Kurz J. H.: NDT and fracture mechanics. How can we improve failure assessment by NDT? Where we are - where we go?, Insight, vol. 53(12), 2011.

[3] B. Szymanik, G. Psuj: Infrared Inspection of Steel Structures Under Load, QIRT 2015.

[4] X. Maladegue: Theory and practice of infrared technology for nondestructive testing, JohnWiley and Sons, 2001

[5] A. Bzymek, et al.: Analysis of images recorded during welding processes, 9th QIRT Conference, 2008, Poland.

[6] Akira DEMIZ, et al.: Development of defect detection method of steel structures by digital image correlation method using induction heating, International Symposium Non-Destructive Testing in Civil Engineering (NDT-CE), 2015, Germany.

[7] G. Psuj, T. Chady, M. Enokizono: Observation of material degradation under fatigue and static loading condition using selected electromagnetic NDT methods, Material Science Forum, vol. 721, 120, 2012, 120-126.

[8] J. Erdmann, H. Huang: Microwave Antenna Sensors for Fatigue Crack Monitoring Under Lap-joints, ASME 2010 Conf. on Smart Materials, Adaptive Structures and Intelligent Systems, Vol. 2

[9] I. Mohammad, H.Huang: Monitoring fatigue crack growth and opening using antenna sensors, Smart Materials and Structures, No. 19, 2010.

[10] F. Chocianowicz :Microstrip antenna based sensor for the detection and monitoring of crack growth in conductive material, Master Thesis, West Pomeranian University of Technology, Szczecin, Poland, 2013.

[11] W. Wang, H. Ge, T. Liu, M. Liu: Study of Patch Antennas for Strain Mesurement, Electromagnetic Nondestructive Evalution (XVIII), 2015.

[12] A. Daliri, A. Galehdar, S. John, W. S. T. Rowe, K. Ghorbani, “Slotted Circular Microstrip Patch Antenna Application in Strain Based Structural Health Monitoring", AlAC14 Fourteenth Australian International Aerospace Congress, 2011.
[13] C.A. Balanis, "Antenna theory analysis and design", 3rd ed, Wiley \& Sons Ltd., 2005.

[14] P., Lopato, G. Psuj, M. Herbko , M. Maciusowicz, "Evaluation of stress in steel structures using electromagnetic methods based on monitoring of $A C$ magnetization process and utilization of microstrip antenna sensor", WD 2016 Conference, Lublin.

[15] O.Stupakov, I. Tomas, "Hysteresis minor loop analysis of plastically deformated low-carbon steel", NDT\&E International, 2006, 39, 554-561.

[16] C. C. H. Lo. et al., "Structural Characterization, and Magnetic Properties of Steels Subjected To Fatigue", Review In Progress of QNDE 19, 509 (2000), 1597-1604.

[17] G. Psuj, „Fusion of Multiple Parameters of Magnetic Testing Results for Damage Assessment of Loaded Steel Structures", Studies in Applied Electromagnetics and Mechanics, Vol 40: Electromagnetic Nondestructive Evaluation (XVI), pp.192-199.

[18] A. Sorsa, "Prediction of material properties based on nondestructive Barkhausen noise measurement", Acta Universitatis Ouluensis, C Technica 442, Oulu, 2013.

[19] L. Padovese, N. Martin, F. Millioz, "Time-frequency and Time-Scale analysis of Barkhausen noise signals", Proceedings of the Institution of Mechanical Engineers. Part G, Journal of Aerospace Engineering, 2009, 223 (5), pp. 577-588.

[20] S. Pawlak, M. Różański, S. Stano, G. Muzia, „Termografia aktywna jako nowa metoda badań nieniszczących połączeń zakładkowych spawanych laserowo", Przegląd Spawalnictwa - Welding Technology Review, Vol 86, No 3 (2014)

[21] D. Mężyk, Magnetyczna ocena naprężeń w instalacjach rurociągowych z wykorzystaniem efektu Barkhausena, Przegląd Spawalnictwa - WeIding Technology Review, Vol 86, No 5 (2014)

[22] D. Kukla, P. Grzywna, R. Karczewski, „Ocena rozwoju uszkodzenia zmęczeniowego na podstawie zmian odkształcenia i parametrów prądowirowych w kolejnych cyklach obciążenia", Przegląd Spawalnictwa - Welding Technology Review, Vol 86, No 5 (2014) 